\title{
Are Non-Muslim Consumers Interested in Foods with the Halal Label?
}

\author{
Fitranty Adirestuty ${ }^{1, *}$ Mochammad Reza Ramdiana ${ }^{2,}$ Agus Rahayu ${ }^{3,}$ Hilda \\ Monoarfa $^{4}$, Azlin Zanariah binti Bahtar ${ }^{5}$ Zamzuri bin Ahmad ${ }^{6}$ Nurazree bin \\ Mahmud $^{7}$
}

${ }^{1}$ Universitas Pendidikan Indonesia
${ }^{2}$ Universitas Pendidikan Indonesia
${ }^{3}$ Universitas Pendidikan Indonesia
${ }^{4}$ Universitas Pendidikan Indonesia
${ }^{5}$ Universiti Teknikal Malaysia
${ }^{6}$ Universiti Teknikal Malaysia
${ }_{7}^{7}$ Universiti Teknikal Malaysia
${ }^{*}$ Corresponding author.Email: fitranty@upi.edu

\begin{abstract}
This study measures attitudes, subjective norms, and behavioral control influence the intention to buy halal-labelled by non-Muslims. The method used in this research is causality with a quantitive approach. The population in this field were non-Muslim students at Parahyangan Catholic University, and the sampling technique was non-probability sampling with the type of sampling used was convenience sampling of 202 respondents. The limitation of this study lies in the respondents who are Catholic Christians only and without involving other religions. The data analysis technique used is Patrial Least Square - Structural Equation Modeling (PLS-SEM). The results showed that attitude and behavior control had a positive and significant effect on purchase intention. Meanwhile, subjective norms did not affect purchase intentions. This research is expected to provide benefits for various parties, especially food producers, to get the MUI halal label because the more non-Muslim people who come here are increasingly aware of the goodness of halal food for the body for a healthy life.
\end{abstract}

Keywords: Attitudes, Subjective Norms, Behavior Control, Purchase Intention, Non-Muslims, Mui Halal Label.

\section{INTRODUCTION}

Today, halal is no longer synonymous with religious matters but is also considered as a standard of choice for Muslim and non-Muslim consumers. Therefore, the concept of halal is familiar to non-Muslim consumers, especially those who live in Muslim countries such as Indonesia and Malaysia [1].

The halal lifestyle has become a global trend that is in a great demand by the whole world. Even the halal lifestyle has become a market to attract tourists, such as the emergence of Muslim friendly in Japan, halal guides in several countries, and various guides for choosing halal food, it is an essential indication of the development of interest in halal products. With the halal market development, companies have started to build their products with the Islamic. As a result, non-Muslim MNCs (e.g., Nestle, Unilever, L'Oreal) also have an increasing interest in addressing Islamic diet, lifestyle, and consumption [2]. The first reason underlying this trend is that the Islamic market is attracting attention from Muslims and non-Muslims who are motivated by the simplicity, purity, and humanity that Islamic brands are considered to have[2]. This research is in line with [3], there is a high demand for halal products in several non-Muslim countries for Muslim and non-Muslim consumers. International trade in the halal food market is extensive and is a fast-growing segment of the world [4]. 
By giving the product a halal logo, the company states that their product is guaranteed and helps Muslim and non-Muslim consumers to choose the best for themselves. With the proliferation of halal products, nonMuslims are starting to realize the existence of products with Islamic labels, so they start to get used to consuming these halal-labeled foods. Regarding the halal logo, reference [5] states that the inclusion of a halal logo on products helps them choose food or drinks that they will consume easily. However, for non-muslim consumers, this is not a something new because almost all food and beverage products on the market are halal-labelled. It is also confirmed by reference [1], who show that at least 75.5 and 79 percents of non-Muslim consumers are aware of the existence of Halal principles and admit that their awareness of Halal principles increases through advertising.

Many non-Muslim consumers choose to buy and consume halal food because it is considered a healthier choice. The concept of halal emphasizes the safety, cleanliness, and usefulness of these foods. The halallabelled foods are believed to be safe foods. So it appears a positive attitude from non-Muslims towards halal products, especially for halal foods --- Non-Muslim consumers have a positive attitude towards the concept of halal and have the intention to buy halal food [6]. According to a study conducted by reference [5], a factor influencing the intention to buy non-Muslim foods is consumer attitudes, because it attracts them to buy a packaged food with halal label from LPPOM-MUI for non-Muslims at UNY. According to this theory, Attitude, Subjective Norms, and Behavior Control are the main factors that influence consumer intentions to buy products [7].

Based on the explanation above, this study develops an understanding of the theory by looking further about the attitudes, subjective norms, and behavior control that affect the intention to buy halal-labelled foods, especially in Indonesia that focuses on non-Muslim students of Parahyangan University.

\section{1Attitude}

An individual's attitude is defined as a person's evaluations of the behavior based on the expected positive and negative results related to behavioral beliefs [8]. Attitude is also an evaluation, emotional feeling, and tendency of an individual to like or dislike an object or idea. Although many definitions of attitude have been put forward, all these definitions have the same thing: attitude is defined as evaluating someone [9] According to reference [10], attitude is a comprehensive evaluation of a person carrying out a behavior. In the theory of reasoned action, a whole attitude or attitude towards a behavior is determined by a strong belief about the behavior called as behavioral belief. Beliefs (behavioral beliefs) are determined by evaluating the outcomes associated with the behavior and determined by the associations' strength.

\subsection{Subjective Norms}

A person's norm represents the perceived social pressure to engage or avoid certain behaviors based on normative assumptions [8]. Furthermore reference [11] explained subjective norms derive from normative beliefs, namely beliefs in specific references. Meanwhile, according to reference [12], subjective norms are a person's perception or view of others' beliefs that will influence the intentions to do or not do the behavior being considered. In detail, [13] explained that some different questions can be formulated to obtain direct measurements of subjective norms. Subjective norms in the form of determinants of the second intention are also assumed to be a function of beliefs. However, A person's beliefs as another dimension refers to a particular individual or group who approves or disapproves of behavior. If it becomes a reference to a direct behavior, the individual or group is called a reference. For some behaviors, some referrals are necessary such as parents, spouses, close friends, co-workers, and, depending on the behavior involved, may also be experts such as doctors or accountants.

\section{3Behavioral Control}

Control is the product of trust, which is the understanding of influences that support or hinder the performance of an action. Perceptions of control can directly affect behavior and indirectly influence behavior by affecting intention [9]. Then in TPB, it is also recommended that perceived control and intention can interact to influence behavior. The impact of intention on behavior might be more substantial if perceived control is high [8].

According to reference [7], behavioral control refers to a person's perception of his/her ability to display particular behavior. In other words, behavior control refers to the extent to which a person feels that displaying or not displaying certain behaviors is under the individual's control. Several beliefs determine behavior control about the existence of factors that can facilitate or complicate the displayed behavior. Behavior is any human activities or activity, either directly observable or not observable by outsiders. It is a person's response and reaction to stimuli from outside stimuli [14].

\section{4Purchase Intention of MUI Halal- Labelled Foods}

According to reference [15] the intention is defined as the desire to perform a behavior. The intention is not in the form of behavior. It does not always static and can change over time. Meanwhile, the desire to behave 
(behavioral intention) in the context of consumer behavior can be defined as the desire of consumers to behave in spesific ways to own, dispose of, and use a product or service.

Purchasing, according to reference [16] that intention is a person's attitude in the conative component. Attitudes express as consumer intentions.

\section{METHODS}

This study employed an explanatory research as an approach through a survey [17]. The research object of this study involves attitudes, subjective norms and behavioural control, and purchase intention. The population in this research were non-Muslim students at Parahyangan University since it is the largest Catholic University in Bandung, where most of the population is Muslim. The sampling technic used was non-probability sampling with the convenience sampling method.

The distribution of questionnaires was carried out by distributing google forms to non-Muslim Parahyangan university students who are members of the WAG administrators of BEM and SENAT at the university, faculty, and study program levels in December 2019, which took approximately two weeks to total 202 respondents. This study used a formative indicator model so that the analytical tool was Structural Equation Modeling, Partial Last Square (SEM-PLS) based on the next page as folow fig. 1 .

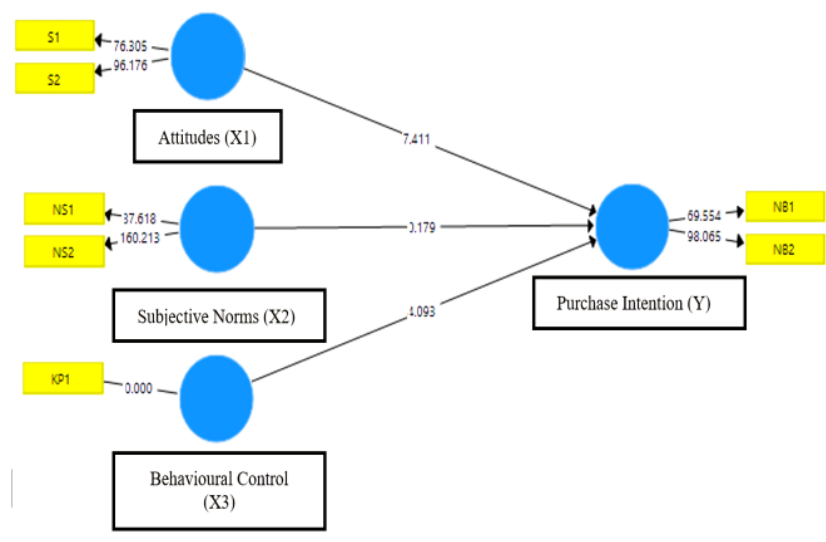

Figure 1 Bootstrap

To see whether the hypothesis is accepted or rejected, it can be seen from the following bootstrap report as following table 1 .

Table 1. Path Coefficient Table

\begin{tabular}{|c|c|c|c|c|c|}
\hline & $\begin{array}{c}\text { Origin } \\
\text { al } \\
\text { Sample } \\
(\mathbf{O})\end{array}$ & $\begin{array}{c}\text { Exampl } \\
\mathbf{e} \\
\text { Everag } \\
\mathbf{e}(\mathbf{M})\end{array}$ & $\begin{array}{c}\text { Standar } \\
\mathbf{d} \\
\text { Deviatio } \\
\mathbf{n} \\
\text { (STDEV } \\
\text { (ST }\end{array}$ & $\begin{array}{c}\text { T } \\
\text { Statistic } \\
(\mathbf{O} \text { O } \\
\text { /STDEV } \\
\mid)\end{array}$ & $\begin{array}{c}\text { P. } \\
\text { Valu } \\
\mathbf{e}\end{array}$ \\
\hline $\begin{array}{c}\text { Behavior } \\
\text { Control }\end{array}$ & 0.326 & 0.320 & 0.072 & 4.502 & 0.000 \\
\hline
\end{tabular}

\begin{tabular}{|c|l|l|l|l|l|}
\hline $\begin{array}{c}\text { (X3)-> } \\
\text { Purchase } \\
\text { Intention } \\
\text { (Y) }\end{array}$ & & & & & \\
\hline $\begin{array}{c}\text { Subjektiv } \\
\text { e Norm } \\
\begin{array}{c}\text { X2) -> } \\
\text { Purchase } \\
\text { Intention } \\
\text { (Y) }\end{array}\end{array}$ & 0.014 & 0.013 & 0.072 & 0.197 & 0.844 \\
\hline $\begin{array}{c}\text { Attitude } \\
\text { (X1)-> } \\
\text { Purchase } \\
\text { Intention } \\
(Y)\end{array}$ & 0.492 & 0.498 & 0.064 & 7.676 & 0.000 \\
\hline
\end{tabular}

\section{RESULTS AND DISCUSSION}

Based on the results of the table above, it can be concluded that the findings in this research found that attitude has a positive and significant effect on purchase intention. It is relevant to the findings of previous studies. The right step to increase purchase intention for nonMuslim consumers is to understand that halal-labelled food is appropriately processed and avoids risks that can endanger health.

This influential attitude towards the intention to buy halal-labelled food is inline with the research conducted by reference [7] entitled "Perception non-Muslim consumers toward purchase product Halal food in Malaysia" with 500 respondents using The Structural Equation Modelling (SEM) method. This findings revealed that there is a positive and significant influence between attitudes toward purchase intention. Besides, this study underlined that attitudes have an essential role in non-Muslim consumers' intention to buy halal food. Likewise, the research conducted by reference [4] entitled "Implementing Theory of Planned Behavior (TPB) in Purchasing Halal Food" conducted in Malaysia by using multiple linear regression methods states that attitude is an essential factor influencing consumers. Intention to buy halal food products because someone who has a positive attitude will have a greater intention to buy halal food products. Other similar studies were conducted by references [5],[18] underlining positive and significant influences between attitude towards purchase intention. According to the theory and previous research, the findings of this research stated that attitudes have a positive and significant influence on purchase intention. Hence, it is a good step to increase the purchase intention of non-Muslim consumers, one of which is to increase the understanding that foods labeled as halal are appropriately processed and avoid risks that can endanger health [19].

In term of subjective norms, it did not affect the purchase intentions. It contradicts the findings of previous research done by references $[4,7,18]$. According to reference [7] explaining that subjective norms significantly affect non-Muslim consumers' intention to buy halal food products. This is because non-Muslim 
consumers in Malaysia were influenced by their friends or family members to consume halal products. On the other hand, the same findings were found by [20] entitled "To Buy or Not to Buy? Consumer Attitudes and Purchase Intentions for Suboptimal Food" with 539 repondents in Taiwan with structural equation modelling (SEM) method. The study showed that there was no influence between subjective norms on purchase intention because consumers do not show a significant effect on purchase intention. Likewise, a research conducted by reference [21] entitled "Antecendent of Purchasing Interest in Natural and Organic Shampoo Products" using the Structural Equation Model (SEM) method noted that a person tends not to need other people's opinions when buying a product. Subject norm variable in this study has two indicators namely normative beliefs and motivation to comply. Subjective norms are social influences that are influenced by a person's external and internal environment to do or not to do something. These normative beliefs indicators state that non-Muslim consumers have not yet considered MUI halal-labelled food to be a high quality one. Besides that, non-Muslim consumers also have not received good information about MUI halal-labelled foods by MUI. Such a motivation to comply indicator claims that the influence of respondents' internal and external environment is the same as a non-Muslim, so nonMuslim consumers unintentionally buy the foods because the respondent's family and friends do not provide motivation or advice to consume food labeled halal. Besides, there was an effect of behavioral control to buy MUI halal-labelled on non-Muslim consumers supporting the theory that behavioral control has a significant effect on purchase intention. The influence of behavioral control towards intention to buy halal-labelled foods is inline with research conducted by [7] entitled "Perceptions of non-Muslim consumers towards purchasing halal food products in Malaysia," resulting a positive and significant between behavior control and purchase intention. This study underlined that consumers formulate their positive effects on halal products because of some value product quality and consider safety, cleanliness, and hygiene. Other studies that have similar results were also found in reseacrh conducted by references [4],[18] claiming that there is a positive and significant effect between attitudes towards purchase intention.

The study about behavioral control variable has two indicators: control beliefs dan perceived power of respondents assessing the average attitude of being in the medium and high categories. Behavioral control means that the better consumer behavior, the higher the consumers' purchase intention for food products labeled halal by MUI. These control belief indicators state that non-Muslim consumers buy or consume food labeled halal because of cleanliness and suitability for personal health. This perceived power indicator states that the perceived ease or difficulty influences it in buying or consuming food labeled halal by MUI; when religious elements are present, and research is categorized as Halal, they will benefit in new markets and have a comparative advantage that will increase their income [22].

\section{CONCLUSIONS}

The attitude of non-Muslim consumers towards MUI halal food is in the medium category. It is shown from the results of the distribution of questionnaires, highlighting the attitude category results included in the moderate category. Then the subjective norms of non-Muslim consumers on MUI halal food fall into the medium category. This research shows non-Muslim consumers' motivation to follow close friends/family views towards MUI halal-labelled foods quite well. Furthermore, controlling the behaviour of non-Muslim consumers towards halal food is in the medium category. It means that non-Muslim consumers have fairly good behavioral control towards the foods. So that food producers are more enthusiastic about getting a halal label or logo from MUI. The reason is, the non-Muslim community is getting here more and more aware of sound, halal food for the body as an interpretation of healthy living.

The findings of this study are in line with the results of the research done by reference [7] concluding that the concept of TPB to determine the factors that affect nonMuslim consumers' perceptions towards halal food products in the context of Malaysia. Attitude, subjective norms, and perceived behavior control were seen as the main factors that dictate halal products' consumption. Additionally, it has also been found that perceived control leads to non-Muslim consumers' intention of consuming halal food products, social influence also affects non-Muslims' intentions regarding the purchase of halal products.

\section{REFERENCES}

[1] R. Golnaz, M. Zainalabidin, S. Mad Nasir, and F. C. Eddie Chiew, 'Non-muslims' awareness of Halal principles and related food products in Malaysia," Int. Food Res. J., 2010.

[2] B. A. Alserhan, "Islamic branding: A conceptualization of related terms," J. Brand Manag., 2010, doi: 10.1057/bm.2010.18.

[3] B. Berry, "Global Halal Food Market," Agric. AgriFood Canada, 2008.

[4] S. Shah Alam and N. Mohamed Sayuti, "Applying the Theory of Planned Behavior (TPB) in halal food purchasing," Int. J. Commer. Manag., 2011, doi: 10.1108/10569211111111676. 
[5] M. Maghfiroh, "Faktor-Faktor Yang Memengaruhi Niat Membeli Makanan Kemasan Berlabel Halal Lppom-Mui," J. Econ., 2017, doi: 10.21831/economia.v11i2.8240.

[6] V. N. Mathew, A. M. R. binti A. Abdullah, and S. N. binti M. Ismail, "Acceptance on Halal Food among Non-Muslim Consumers," Procedia - Soc. Behav. Sci., 2014, doi: 10.1016/j.sbspro.2014.01.1127.

[7] A. Haque, A. Sarwar, F. Yasmin, A. K. Tarofder, and M. A. Hossain, 'Non-muslim consumers' perception toward purchasing halal food products in malaysia," J. Islam. Mark., 2015, doi: 10.1108/JIMA-04-2014-0033.

[8] S. E. Zemore and I. Ajzen, "Predicting substance abuse treatment completion using a new scale based on the theory of planned behavior," J. Subst. Abuse Treat., 2014, doi: 10.1016/j.jsat.2013.06.011.

[9] A. de Leeuw, P. Valois, I. Ajzen, and P. Schmidt, "Using the theory of planned behavior to identify key beliefs underlying pro-environmental behavior in high-school students: Implications for educational interventions," J. Environ. Psychol., 2015, doi: 10.1016/j.jenvp.2015.03.005.

[10] P. Thomas and A. Selimovic, "'Sharia on a Plate?' A critical discourse analysis of halal food in two Norwegian newspapers," J. Islam. Mark., 2015, doi: 10.1108/JIMA-05-2014-0041.

[11] R. Fraser, I. Ajzen, K. Johnson, J. Hebert, and F. Chan, "Understanding employers' hiring intention in relation to qualified workers with disabilities," $J$. of Vocational Rehabilitation. 2011, doi: 10.3233/JVR-2011-0548.

[12] M. A. Ashraf, "Islamic marketing and consumer behavior toward halal food purchase in Bangladesh: An analysis using SEM," J. Islam. Mark., 2019, doi: 10.1108/JIMA-03-2018-0051.

[13] O. S. Al-Kwifi, A. Abu Farha, and Z. U. Ahmed, "Dynamics of Muslim consumers' behavior toward Halal products: Exploration study using fMRI technology," Int. J. Emerg. Mark., 2019, doi: 10.1108/IJOEM-11-2017-0486.

[14] T. Nurhayati and H. Hendar, "Personal intrinsic religiosity and product knowledge on halal product purchase intention: Role of halal product awareness," J. Islam. Mark., 2019, doi: 10.1108/JIMA-11-2018-0220.

[15]Z. A. Bin Abdul Latiff, G. Rezai, Z. Mohamed, and M. Amizi Ayob, "Food Labels' Impact Assessment on Consumer Purchasing Behavior in Malaysia," $J$.
Food Prod. Mark., 2016, doi: 10.1080/10454446.2013.856053.

[16] M. Muslichah, R. Abdullah, and L. Abdul Razak, "The effect of halal foods awareness on purchase decision with religiosity as a moderating variable: A study among university students in Brunei Darussalam," J. Islam. Mark., 2019, doi: 10.1108/JIMA-09-2017-0102.

[17] U. Sekaran and R. Bougie, "Research Method For Business -Metode Penelitian Untuk Bisnis.," Encycl. Qual. Life Well-Being Res., 2014.

[18] S. Putra and R. Nurdin, "Penerapan Theory of Planned Behavior Dalam Pembelian Makanan Halal Pada Masyarakat Di Kota Banda Aceh," J. Ilm. Mhs. Ekon. Manaj., 2017.

[19] I. Ismail, N. A. Nik Abdullah, Z. Ahmad, and N. L. Sidek, "Halal Principles and Halal Purchase Intention Among Muslim Consumers," in Proceedings of the 3rd International Halal Conference (INHAC 2016), 2018.

[20] S. L. Wong, C. C. Hsu, and H. S. Chen, "To buy or not to buy? Consumer attitudes and purchase intentions for suboptimal food," Int. J. Environ. Res. Public Health, vol. 15, no. 7, 2018, doi: 10.3390/ijerph15071431.

[21] A. Haro, "Anteseden Dari Minat Pembelian Produk Shampo Natural Dan Organik," JRMSI - J. Ris. Manaj. Sains Indones., vol. 6, no. 1, p. 479, 2015, doi: 10.21009/jrmsi.006.1.08.

[22]S. Shakil and S. Majeed, "Brand Purchase Intention and Brand Purchase Behavior in Halal Meat Brand,", J. Mark. Logist., 2018.

[23] Hussain, I., Rahman, S. U., Zaheer, A., \& Saleem, S. (2016). Integrating factors influencing consumers' halal products purchase: Application of theory of reasoned action. J. of International Food and Agribusiness Marketing, 28(1). https://doi.org/10.1080/08974438.2015.1006973

[24] Teng, Phuah Kit. (2013). Awareness, Recognition and Intention: Insights From A NonMuslim Consumer Survey Regarding Halal Labeled Food Products in Malaysia. 3rd International Conference on Management. 